\title{
Morphological and molecular evidence of a possible hybrid zone of Leptidea sinapis and L. reali (Lepidoptera: Pieridae)
}

\author{
Rudi VEROVNIK ${ }^{1}$ and PRIMOž GLOGOVČAN ${ }^{2}$ \\ ${ }^{1}$ University of Ljubljana, Biotechnical Faculty, Department of Biology, Večna pot 111, SI-1000 Ljubljana, Slovenia; \\ e-mail: rudi.verovnik@bf.uni-lj.si \\ ${ }^{2}$ Čirče 39, SI-4000 Kranj, Slovenia
}

Key words. Pieridae, Leptidea, hybrid zone, mtDNA, RAPD, cryptic species, distribution, habitat

\begin{abstract}
Overlapping measurements in the length of the genitalia of Leptidea sinapis/reali collected in Slovenia triggered an investigation of a possible natural hybridization between these two well known sibling species of butterflies. Random polymorphic DNA (RAPD) was used to generate species specific markers and sequences of the cytochrome oxidase subunit one gene for determination of the progeny. RAPD's clustering and mitochondrial DNA (mtDNA) phylogeny were congruent with the taxonomic placement of specimens of both species, but slightly incongruent with the results of the analysis of genital morphology. Two specimens with $L$. reali genitalia measurements, but genetically belonging to $L$. sinapis, had species specific RAPD markers of both species indicating probable hybrid origin. All the specimens with genitalia of intermediate length were also genetically assigned to $L$. sinapis indicating a possible one way introgression as predicted from their genitalia morphology. Leptidea sinapis was found predominantly in xerothermic habitats in Slovenia, whereas L. reali was more of a generalist except in the sub-Mediterranean region where it is limited to humid meadows.
\end{abstract}

\section{INTRODUCTION}

The discovery of a new species of wood white (Leptidea sp.) at the end of the 20th century in Europe was one of the most striking novelties in butterfly systematics. The species could have remained undiscovered but for the odd "L. sinapis" population in the French Eastern Pyrenées flying simultaneously in two seasonal forms (Réal, 1962). Réal did not recognize two distinct species at that time and named this phenomenon "amphiphenotism". It was Lorković who first discovered the bimodality in genitalia length of these specimens and suggested to Réal that two species with distinct phenism were present. Réal (1988) described the monovoltine population with long aedeagus and saccus as L. lorkovicii, but the name was invalid and was replaced by $L$. reali Reissinger, 1989. Over the next four years nobody seems to have noticed the surprising discovery of a new species in Europe and it was again Lorković (1993) who draw attention to $L$. reali with his comparative study of the morphometrics of its genitalia, wing patterns, ecology and larval food choice. One of Lorković's major discoveries was that $L$. reali is generally bivoltine or polyvoltine as $L$. sinapis (Linnaeus, 1758) and widespread in Europe, triggering further discoveries and studies of this neglected species.

Possibly one of the main reasons for the lack of studies on $L$. reali at that time was the incomprehensibility of the discovery and skepticism regarding separate species status. Bimodality in genitalia length, as the major argument for separation, was used previously by Reverdin (1920, 1922) in describing a sibling species of Melitaea athalia (Rottemburg, 1775). His description however, was premature as bimodality of male genitalia length was lost in a wide hybrid zone between the two taxa (Bourgogne, 1953). The bimodality of the genitalia length was used also for separation of the two far east Asian wood whites Leptidea morsei Fenton, 1881 and L. lactea Lorković, 1950 (Lorković, 1950, 1993), which is also not widely accepted species. Separate species status of both these less well known Leptidea was confirmed by molecular studies (Martin et al., 2003), with L. lactea not even being the closest relative of $L$. morsei.

Both $L$. sinapis and $L$. reali show great plasticity in wing patterns with pronounced seasonal forms and local variations (Lorković, 1993; Mazel, 2000, 2001a). Only a small proportion of males with a typical shaped black spot on the apex of the forewing (Freese \& Fiedler, 2004) could thus be identified in field. This somewhat hinders large scale ecological studies, but some differences in habitat preferences and choice of plant for oviposition was already reported by Lorković (1993). His findings were largely corroborated by Beneš et al. (2003) in the Czech Republic and Slovakia, and Amiet (2004) in southern France. The oviposition preferences are less pronounced in captivity where different herbaceous Leguminosae were utilized by both species (Freese \& Fiedler, 2002).

Currently the distribution of $L$. reali extends from Spain (Lorković, 1993; Mazel \& Leestmans, 1996), over most of Europe (Lorković, 1993; Laštůvka et al., 1995; Kristal \& Nässig, 1996; Mazel \& Leestmans, 1996, 1999b; Karsholt, 1999; Palmquist, 1999; Abadijev, 2001; Nelson et al., 2001; Beneš et al., 2002), to central Siberia (Mazel, 2001b). Leptidea reali has not been found in England (Asher et al., 2001) and Portugal (Maravalhas, 


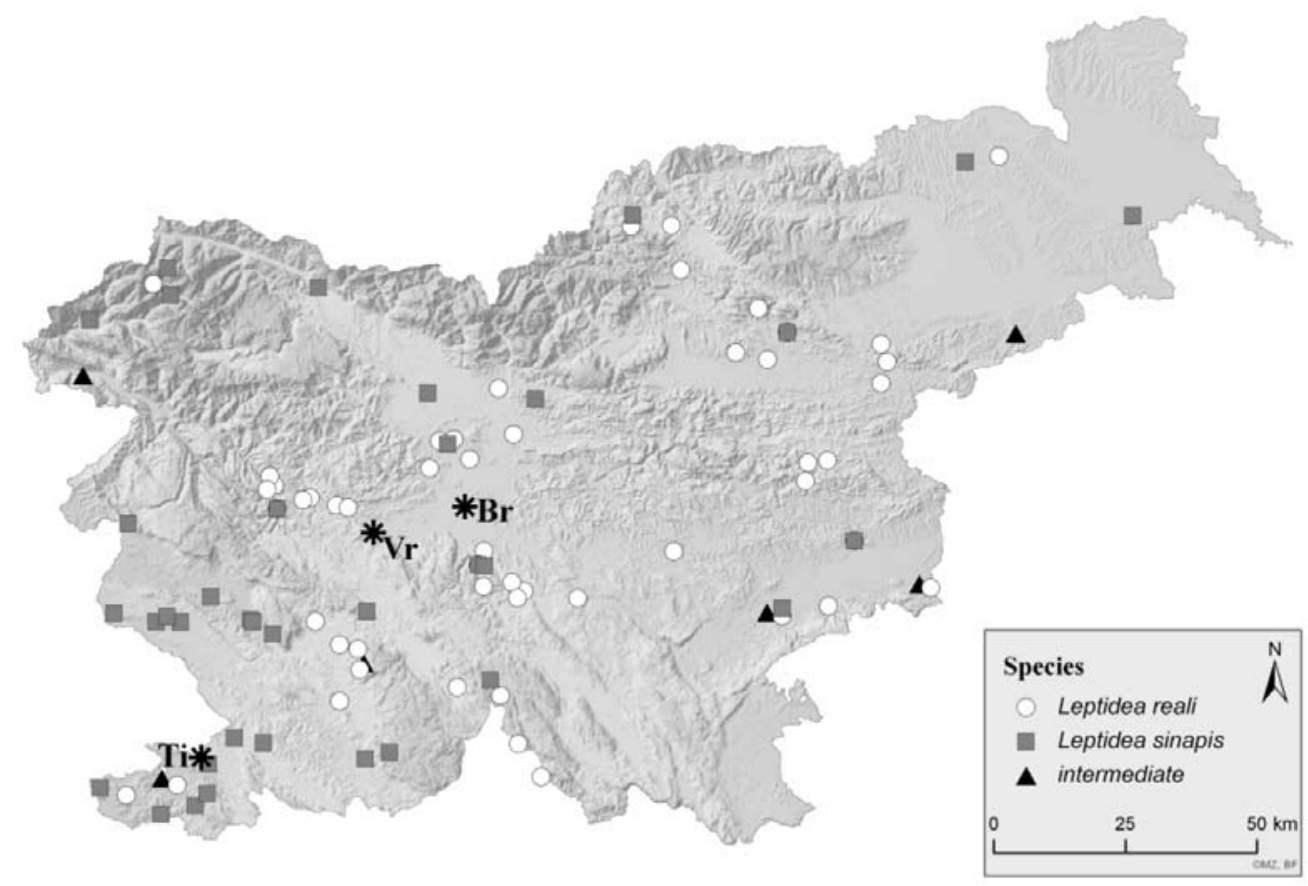

Fig. 1. Distribution of Leptidea sinapis, L. reali, and unidentified specimens with intermediate length of male genitalia in Slovenia. Collection sites: $\mathrm{Br}$ - Barje; Ti - Tinjan; $\mathrm{Vr}-$ Vrhnika.

2003), and has become extinct in the Netherlands (Bos et al., 2006). No hybrid zone between these species is reported, but there is only a single molecular study that could confirm hybridization (Martin et al., 2003). There is also no hybridization in captivity where females of both species discriminated between males during mate choice (Freese \& Fiedler, 2002, Friberg et al., 2007).

Our first objective was to determine the distribution of both species in Slovenia and to describe their habitat preferences. As there were several unidentifiable specimens and lack of a clear bimodal distribution in length of male genitalia, we used population samples from three sites to check for possible hybrids. We used random polymorphic DNA (RAPD) for a technically straightforward generation of a large number of nuclear genetic markers (Williams et al., 1990). Numerous authors have demonstrated that RAPD data can provide a useful tool for detection of hybrids in plants (Boecklen \& Howard, 1997; De Greef \& Triest, 1999; Rajora \& Rahman, 2003) and animals (Chu et al., 1995; Negro et al., 2001; Jug et al., 2004; Mikuliček et al., 2004). Mitochondrial DNA (mtDNA) sequences inherited only maternally were used as a second set of molecular markers.

\section{MATERIAL AND METHODS}

\section{Sampling}

Three sites for molecular studies were selected based on the distribution of both Leptidea species in Slovenia and their habitat preferences (Beneš et al., 2003; Amiet, 2004). The site in the coastal region of Slovenia, Tinjan (Ti), was selected in a region with almost no L. reali records (Fig. 1) and within a typical $L$. sinapis habitat - dry partly overgrown grasslands. The other two sites are situated in central Slovenia where $L$. reali occurs sympatrically with L. sinapis (Lorković, 1993, this study). The two sampling sites are in the Ljubljansko barje depression and are separated by approximately $15 \mathrm{~km}$ of flatlands. The site Vrhnika (Vr) is on the western edge of the depression on elevated calcareous slopes with dry partly overgrown grasslands and deciduous forest $-L$. sinapis habitat. The site Barje (Br) includes mainly wet meadows and hedgerows - a typical $L$. reali habitat. Thus we expected a different ratio of both species at these sites. Twenty males were collected at each site and immediately frozen. The last third of their abdomen and wings were cut off for morphological analysis, the rest was stored in $96 \%$ alcohol at $-20^{\circ} \mathrm{C}$. Specimens from other sites, where only the morphology was studied, were selected from the zoological collection of the Department of Biology, Biotechnical faculty, University of Ljubljana. All specimens were identified by dissection of their genitalia. The genitalia were macerated using $15 \% \mathrm{KOH}$ at $70^{\circ} \mathrm{C}$ for $20 \mathrm{~min}$, cleaned and transferred into glycerin. All measurements were done using a stereomicroscope and program Olympus DP-soft (Olympus, Tokyo, Japan).

\section{DNA extraction, amplification and sequencing}

Genomic DNA was extracted from specimens using a modified Mouse tail protocol of the Nucleospin Tissue kit (Macherey-Nagel, Düren, Germany) as described in Verovnik et al. (2003). A set of 40 decamer primers from UBC (University of British Columbia, Vancouver, Canada) was screened for those that produced repeatable and clearly visible fragment patterns. The selection of primers was based solely on the repeatability of patterns, not on the degree of polymorphism displayed by a primer (Clark \& Lanigan, 1993). Following primers were chosen for the analysis: UBC-519, UBC-521, UBC-725 and UBC-750. In addition an approximately $700 \mathrm{bp}$ fragment of the first subunit of cytochrome oxidase mitochondrial gene (COI) was amplified using primers LCO1490 and HCO2198 (Folmer et al., 1994) for 25 specimens from all sites and species.

Random polymorphic DNA (RAPD) PCR was performed in a total volume of $20 \mu \mathrm{l}$ containing $40 \mathrm{ng}$ and $20 \mathrm{ng}$ of sample 
DNA, $1.5 \mu \mathrm{l}$ of $10 \mu \mathrm{M}$ primer, $2.5 \mu \mathrm{l}$ dNTPs ( $2 \mu \mathrm{M}$ each), $2 \mu 1$ $10 \times$ PCR-buffer (supplied), $1.5 \mu 1 \mathrm{MgCl}_{2}$ (50 mM) (supplied), 0.5 U of Taq Polymerase (Gibco BRL, Gaithersburg, MA, USA) and $11.5 \mu 1$ of the cell culture water. The amplification was performed in a GenAmp PCR system (AB, Foster City, CA, USA) programmed for 45 cycles of 1 min denaturating at $94^{\circ} \mathrm{C}, 1 \mathrm{~min}$ of annealing at $36^{\circ} \mathrm{C}$, and $2 \mathrm{~min}$ of extension at $72^{\circ} \mathrm{C}$, after an initial denaturation of $5 \mathrm{~min}$ at $94^{\circ} \mathrm{C}$. The program was followed by an extension phase at $72^{\circ} \mathrm{C}$ for $10 \mathrm{~min}$. To test the reproducibility of the RAPD patterns obtained, all samples were amplified for a second time with half the amount of DNA in the mixture. All PCR products were subjected to electrophoresis on $1.5 \%$ agarose gels stained with ethidium bromide and photographed under UV light. To enable comparison between gels all electrophoretic and photographing procedures were standardized.

The amplification of COI fragment was done with initial denaturation of $3 \mathrm{~min}$ at $94^{\circ} \mathrm{C}$ followed by 34 cycles of $45 \mathrm{~s}$ at $94^{\circ} \mathrm{C}, 45 \mathrm{~s}$ at $48^{\circ} \mathrm{C}$, and $1 \mathrm{~min}$ at $72^{\circ} \mathrm{C}$, and ended by an extension phase at $72^{\circ} \mathrm{C}$ for $3 \mathrm{~min}$. The PCR products were eluted directly from agarose gels and sequenced using the Thermo Sequenase ${ }^{\mathrm{TM}}$ Cycle Sequencing kit (AP Biotech, Uppsala, Sweden) and dye-labelled primers Cy5-LCO or Cy5-HCO. Sequencing products were analyzed on an Alf Express II automated DNA sequencer (AP Biotech).

\section{RAPD analysis}

RAPD fragments were coded in a binary matrix as present or absent for all specimens. The repeatability of the RAPD amplification was checked first, and only fragments that occurred in both amplification reactions with different template DNA concentrations were included in further analyses. Distance matrix using (1-D) Dice's similarities were computed with RAPDPLOT 3.0 program of Black (1997). To test the support for individual branches bootstrap analysis generating 1000 distance matrices was used in the same program. The resulting distance matrices were then subjected to UPGMA analysis using the option NEIGHBOR of the PHYLIP 3.5 program package (Felsenstein, 1993). CONSENSE from the same package was applied to produce a bootstrap consensus dendrogram.

\section{Sequence analysis}

All mutational changes were base pair substitutions, and no indels were found. Analysis was performed on a 674 bp alignment containing no gaps or missing data. Two outgroup COI sequences, Pieris rapae (Linnaeus, 1758) (Pierinae) and Dismorphia zathoe Hewitson, 1858 (Dismorphiinae) were added from the GenBank. A further L. sinapis from Spain was also added (Braby et al., 2006). Parsimony searches, using the betatest version (4b10) of Win-PAUP* 4.0 (Swofford, 2001), were performed with random addition sequence of haplotypes and no branch swapping. 176 equally parsimonious trees were found, and a strict, consensus tree was calculated. A bootstrap analysis of maximum parsimony (MP) trees using 1000 pseudoreplicates was performed with beta-test version (4b10) of Win-PAUP* 4.0 using the heuristic search option.

For Bayesian inference, the program MrBayes, version 3.0b4 (Huelsenbeck \& Ronquist, 2001) was used. Hierarchical likelihood tests (Posada \& Crandall, 1998) were employed in order to test alternative models of evolution, employing MrModeltest 2.2 (Nylander, 2004). A GTR+I model of nucleotide substitution with significant proportion of invariable sites was selected. Uniform or fixed default prior settings were used. A Markov chain Monte Carlo search was run with four chains for $2 \times 10^{6}$ generations, taking samples every 100 generations. The approximate number of generations needed to obtain stationarity of the likeli-

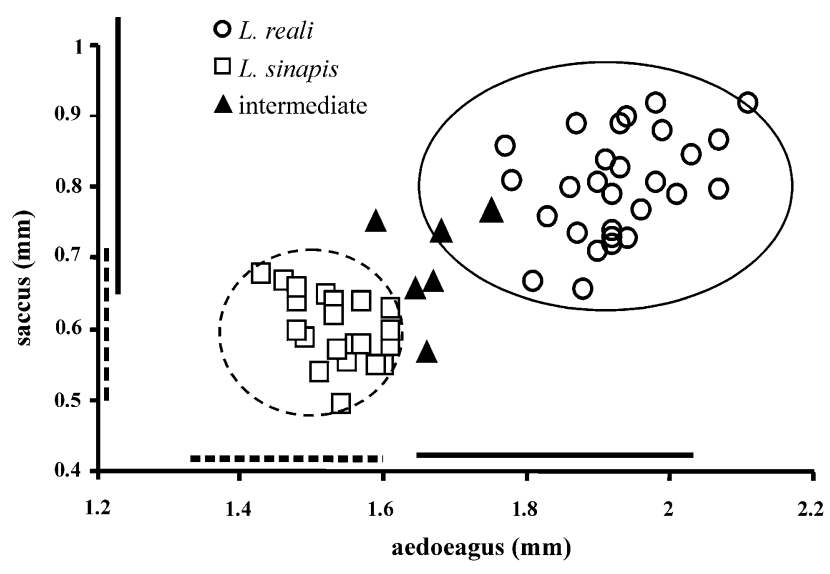

Fig. 2. Correlation between variability in the length of the aedeagus and saccus of Leptidea sinapis and L. reali from three sites in Slovenia, where the molecular studies were performed.

hood values ("burn-in") of the sampled trees was estimated graphically, and was 500. From the resulting trees posterior probabilities were assessed for individual clades based on their observed frequencies.

\section{RESULTS}

\section{Distribution}

Although by no means complete, the distribution map (Fig. 1) indicates a wide distribution of both species in Slovenia with $L$. reali being more widespread in the continental region and $L$. sinapis more common in the subMediterranean region. The L. sinapis/reali species complex is so far recorded from $78.8 \%$ of the $5 \times 5 \mathrm{~km}$ grid squares in Slovenia, therefore both species have a wide distribution. Leptidea reali is generally more common (53 sites, $4.8 \%$ of the squares) than L. sinapis (29 sites, 3.1\% of the squares). The specimens with intermediate ratio of saccus and aedeagus length (intermediate specimens) were found in different parts of Slovenia. Both species have a predominantly colline to submontane distribution with a single record of $L$. sinapis from the alpine region at $1600 \mathrm{~m}$ (Mazel \& Leestmans, 1999b). As mainly single specimens were dissected per site, the level of syntopic occurrence was not evaluated.

Habitat data were available for 68 sites. Habitat descriptions were not detailed but allowed categorization to humid $(\mathrm{H})$, mesophillous (M) and xerothermic (X) habitats. The two species differed significantly in their habitat choice $\left(\chi^{2}=7.74,2\right.$ d.f., $\left.\mathrm{P}<0.025\right)$ with $L$. sinapis mainly present in xerothermic habitats $(\mathrm{H}=1, \mathrm{M}$ $=5, \mathrm{X}=19)$. Leptidea reali was well represented in all habitat categories $(H=12, M=11, X=19)$ with no clear preferences. As expected only L. sinapis was collected on dry grasslands in the coastal region at Tinjan (Ti). It was more surprising that $L$. reali was by far more frequent at both continental sites with extremely different habitats. Only a single $L$. sinapis was found in wet grasslands at Barje (Br), and two were present in dry partially overgrown calcareous grasslands near Vrhnika (Vr). 
TABLE 1. The identification of unidentified specimens of the Leptidea sinapis/reali species complex by different methods. Only reproducible species specific RAPD fragments are included. The percentage of species specific fragments present is indicated in the parentheses.

\begin{tabular}{cccccc}
\hline Specimen & L. reali specific fragments & L. sinapis specific fragments & RAPD's & mtDNA & Morphology of genitalia \\
\hline Vr10 & $5(16.1 \%)$ & $4(25 \%)$ & L. sinapis & L. sinapis & L. reali \\
Vr03 & $2(6.5 \%)$ & $2(12.5 \%)$ & L. sinapis & L. sinapis & L. reali \\
Vr14 & - & - & - & L. sinapis & $?$ \\
Vr15 & - & $1 *(6.3 \%)$ & - & L. sinapis & $?$ \\
Vr16 & - & - & - & L. sinapis & $?$ \\
Ti04 & 0 & $6(37.5 \%)$ & L. sinapis & L. sinapis & $?$ \\
\hline
\end{tabular}

* Only a single primer gave reproducible results.

\section{Morphology}

The shape of the apical black spot on the upper side of the forewing has been suggested as the best diagnostic character for discriminating between the males of $L$. reali and L. sinapis, especially in the first generation (see Fig. 6 in Freese \& Fiedler, 2004). The shape of the black spot was highly variable in the specimens studied, but when the morphology of their genitalia and molecular markers of only specimens from both extremes of the character state were checked the identification of all the L. sinapis, and $75 \%$ of the $L$. reali males was confirmed. Whether the shape of the apical black spot is a useful character for quick identification in the field remains to be tested.

To reduce the number or results plotted on the graph (Fig. 2) only measurements of aedeagus and saccus of the specimens from three sites selected for the molecular

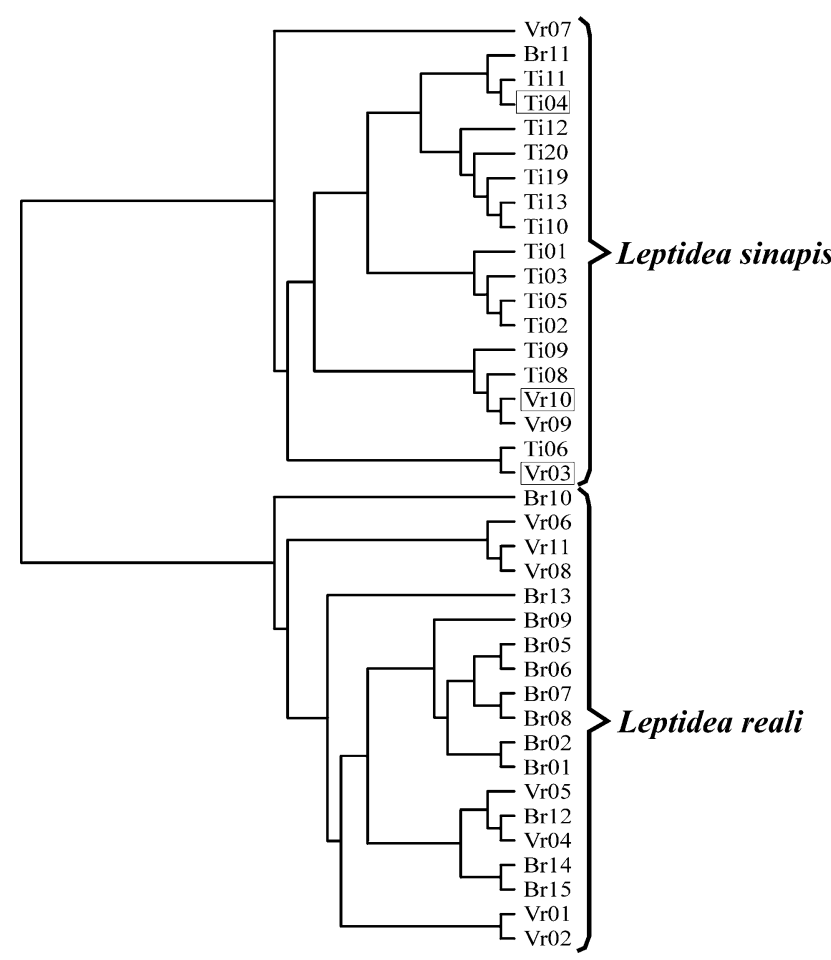

Fig. 3. UPGMA dendrogram of 38 individuals of Leptidea sp. based on pair wise Dice's similarities. Boxes indicate specimens with intermediate genitalia length or incongruent placement by morphological and molecular methods. The codes for the populations are explained in the Materials and Methods and their geographic position in Slovenia is indicated in Fig. 1. studies are included. The intervals of sizes of both structures were taken from Lorković (1993) for Croatian material. According to his observations the length of the genitalia are geographically dependant with specimens of both species from the western part of their range (Pyrenées orientales) having proportionally longer aedeagus and saccus. Although the majority of the specimens sampled from three selected sites could be unambiguously assigned to a species and the length ratio showed a generally bimodal distribution, there were several specimens which either had an aedeagus of intermediate length, long saccus with short aedeagus, or were morphometrically $L$. reali, but genetically belonged to $L$. sinapis. These unidentified specimens indicate a greater phenotypic plasticity and overlap in shape of genitalia as previously reported (Lorković, 1993; Kristal \& Nässig, 1996; Mazel \& Leestmans, 1996; Mazel \& Leestmans, 1999a).

\section{RAPD markers}

Clear fragment patterns were obtained with each of the 4 primers used in the final analysis. From 20 to 50 repeatable marker fragments were scored per primer across all specimens analyzed, yielding a total of 125 fragments. Species specific fragments were identified for specimens with congruent morphological and molecular identification. 31 fragments were diagnostic for $L$. reali and 16 for L. sinapis. On average $27.3 \pm 9.9 \%$ SD of the specific fragments were scored per specimen in L. reali and 37.1 $\pm 11.3 \%$ SD in L. sinapis. In three unidentified specimens that produced repeatable RAPD patterns, diagnostic fragments of both species were present (Table 1) indicating a recent gene flow between both species, i.e. hybridization. However, the percentage of diagnostic fragments was low in all combinations except for $L$. sinapis markers in specimen Ti04 from Tinjan.

In the UPGMA dendrogram (Fig. 3), two main groups were identified roughly corresponding to the morphometric separation of both species. There were only two exceptions - the specimens $\mathrm{Vr} 03$ and $\mathrm{Vr} 10$ with $L$. reali genitalia were clustered with the $L$. sinapis specimens. The Ti04 specimen clustered with L. sinapis as expected from the presence of 6 diagnostic marker fragments for this species. The bootstrap support was low for all except a few higher level clusters including specimens from a single site. 


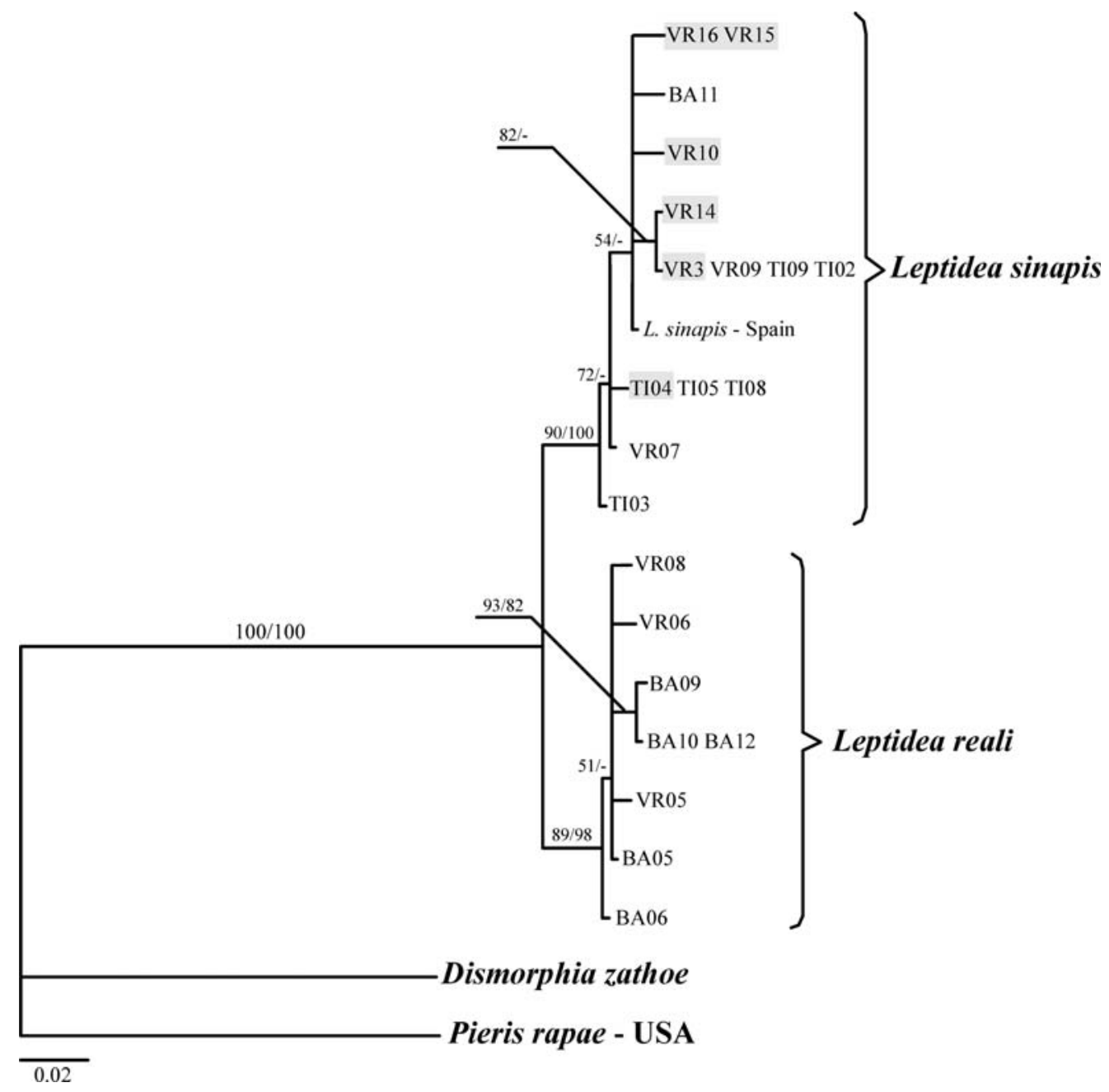

Fig. 4. Genealogical relationships of Leptidea sp. COI mitochondrial DNA haplotypes derived from 18250 Bayesian trees. Posterior probabilities calculated from Bi trees and the bootstrap support of MP trees, respectively, is given above the branches. Grey shading indicates specimens with intermediate genitalia length or incongruent placement by morphological and molecular methods. The codes of populations are explained in the Materials and Methods and their geographic position in Slovenia is indicated in Fig. 1.

\section{mtDNA}

Among 26 specimens examined of both Leptidea species, 16 unique COI haplotypes were identified. All sequences are deposited in the GenBank Nucleotide Sequence database under Accession numbers EF599632 EF599646. The length of the aligned COI sequences is $674 \mathrm{bp}$. Of the $23(3.4 \%)$ variable characters within the Leptidea clade, 21 (3.1\%) are parsimony informative. The mean Kimur 2-parametric genetic distance between $L$. reali and $L$. sinapis is $2.50 \pm 0.63 \% \mathrm{SD}$. This is similar to the distance $(3 \%)$ reported for more slowly evolving t-RNA coding mtDNA genes partially included in the phylogenetic study of Leptidea species of Martin et al. (2003). The divergence of COI between L. sinapis and $L$. reali is within the range observed for fully distinct species of butterflies (Aubert et al., 1997; Hebert et al., 2004).

Parsimony analysis yielded 176 equally parsimonious trees 162 steps long with a consistency index $(\mathrm{CI})=$ 0.9383 , retention index $(\mathrm{RI})=0.9425$ and rescaled consistency index $(\mathrm{RC})=0.8843$. Bayesian $(\mathrm{BI})$ and parsimony (MP) approach produced phylogenies with congruent basal topology supporting separation of both Leptidea species (Fig. 4). Monophylly of both species was supported by high bootstrap values $(100,98 \%)$ and moderate posterior probabilities $(90,89 \%)$. Within species relationships were unresolved in the MP strict consensus tree (data not shown) and did not reveal any geographic structuring in the Bi tree (Fig. 4). Actually the Tinjan and Vrhnika population of L. sinapis which were separated by $56 \mathrm{~km}$ had one haplotype in common, and $L$. sinapis from Spain was nested within the Slovenian haplotypes. All intermediate specimens were assigned to $L$. sinapis. As mtDNA is inherited only maternally the female parent of the intermediate males was certainly $L$. sinapis.

\section{DISCUSSION}

Distribution of the recently separated Leptidea species in Slovenia is known only from a few published records (Lorković, 1993; Embacher, 1996; Mazel \& Leestmans, 1999b). Although the new records are a substantial addition (Fig. 1) the distribution of both species in Slovenia is 
still insufficiently known. However, even from the limited data available, the differences in distribution are evident and in line with the ecological preferences of both species (Beneš et al., 2003; Amiet, 2004). Leptidea sinapis is widespread in the warmer sub-Mediterranean part of Slovenia and $L$. reali in the continental region. In southern Europe $L$. reali has a more restricted distribution (Mazel \& Leestmans, 1999b; Abadijev, 2001; Amiet, 2004) correlated with the availability of the preferred host plant Lathyrus pratensis which is confined here to humid habitats. In this region L. sinapis is a generalist, with several host plants in different habitats (Amiet, 2004). The situation seems to be reversed in central and northern Europe, where L. sinapis is limited to xerothermic habitats (Warren \& Bourn, 1998; Beneš et al., 2003; Bos et al., 2006) and L. reali is more widespread (Kristal \& Nässig, 1996; Karsholt, 1999; Beneš et al., 2003). This latitudinal influence on their distribution pattern cannot be generalized as England (Asher et al., 2001), northern Germany (Kolligs, 2003) and the Netherlands have no $L$. reali. The early extinction of $L$. reali in the Netherlands (Bos et al., 2006) is particularly puzzling as potential habitats and the larval food plant are still widespread there (Van Swaay, pers. comm.).

L. sinapis is a typical xerothermic butterfly in Slovenia with only marginally higher abundances in other habitats than in the Czech Republic (Beneš et al., 2003). Its wider distribution in the sub-Mediterranean part of Slovenia may simply be explained by the greater habitat availability and not relaxed habitat requirements as in southern France (Amiet, 2004). The suitable habitats for $L$. reali are much more limited in this part of Slovenia and the two sites where it is present near the coast are humid grasslands. In the continental region habitat segregation is less obvious with both species occurring in all types of habitat. At both inland sites studied $L$. reali was much more frequent regardless of the habitat. Further studies are needed to establish the level of sympatry and proportions of both species in different habitats.

The relationship between $L$. sinapis and $L$. reali is described as "almost perfect" sibling species with clear distinction in genitalia measurements, mtDNA sequences and no hybrids detected by allozyme studies (Martin et al., 2003). However, none of the 16 allozyme loci analyzed in that study was completely diagnostic, and few morphologically ambiguous individuals were found, therefore hybridization should not have been entirely ruled out. A broader overlap in the genitalia measurements of males of both species is also found in reared specimens (Freese \& Fiedler, 2004). The slight morphological overlap would allow hybridization (Martin et al., 2003) but as shown convincingly by Lorković (1993) only between male $L$. reali and female $L$. sinapis. Hybridization in butterflies is not rare and natural hybrids occur between well known species like Zerynthia polyxaenalrumina (de Puységur, 1947), Parnassius apolllo/phoebus (Descimon et al., 1989), Erebia pronoelepiphron (Bourgogne, 1963) etc. In the case of $L$. sinapis/reali, sympatric and even syntopic occurrences are widespread throughout the European range of both species (Embacher, 1996, Beneš et al., 2003; Martin et al., 2003; Amiet, 2004; Friberg et al., 2007; this study), and all these regions are potential hybrid zones.

Our results indicate a high possibility of a hybrid zone between $L$. sinapis and $L$. reali in Slovenia. This is manifested by the lack of an evident gap in the ratio of the length of the aedeagus and saccus (Fig. 2) and incongruence between morphological and molecular data with two morphologically $L$. reali specimens identified genetically as L. sinapis by RAPD's (Fig. 3) and mtDNA phylogeny (Fig. 4). As mtDNA is inherited maternally this would imply a $L$. sinapis female and $L$. reali male parent. This was confirmed by the presence of both $L$. reali and $L$. sinapis species specific fragments in these two specimens (Vr10, Vr03). As no reproducible RAPD profiles are available for the three intermediate specimens ( $\mathrm{Vr} 14, \mathrm{Vr}$ 15, Vr16) hybridization could not be confirmed. The Tinjan specimen (Ti04) had the length of saccus placing it in $L$. reali with all other data congruent with $L$. sinapis (Table 1 ). As there is no L. reali population in the vicinity hybridization is unlikely, and this specimen (Ti04) should be considered as L. sinapis with anomalous genitalia.

As indicated by the morphological constrains (Lorković, 1993) introgression is possible only in one direction, with female $L$. sinapis inseminated by male $L$. reali. This is clearly in line with our results placing both hybrids in L. sinapis mtDNA clade and RAPD cluster. Leptidea reali/sinapis are known for their pre-mating courtship (Wiklund, 1977), and this together with chemical signalling could be the most important prezygotic isolating mechanism (Freese \& Fiedler, 2002). This was confirmed by breeding experiments, in which interspecific courtship was commonly observed but never successful due to female choice (Freese \& Fiedler, 2002). If we consider that these prezygotic barriers are being crossed from time to time, there must be a strong postzygotic barrier hindering further blending of these two closely related species. Sterility or inviability of hybrids is often the most evident mechanism, but should be confirmed for Leptidea by crossing experiments. According to Haldane's rule (Haldane, 1922) genetic incompatibility resulting in sterility should be more pronounced in the heterogametic sex. In butterflies this is the female sex, and the effects of Haldane's rule in butterflies have been confirmed (Sperling, 1993; Aubert et al., 1997; Jiggins et al., 2001; Naisbit et al., 2002; Presgraves, 2002). This implies that maternally inherited molecular markers can only rarely penetrate the species barriers. However, breeding experiments using backcrossing (Descimon \& Michel, 1989, Aubert et al., 1997) and studies of butterfly hybrid zones (Porter \& Geiger, 1995; Porter et al., 1997) have shown that viability of hybrids is not necessarily reduced. In hybrid zones between Pontia daplidice/P. edusa (Porter et al., 1997) and Pieris napi/P. bryoniae/P. meridionalis (Porter \& Geiger, 1995) allozyme studies detected only weak genetic isolation, and pairs of taxa are considered conspecific. Hybridization between L. sinapis and $L$ reali seems to be rare. Given the congruence of the 
RAPD's and mtDNA results in deliminating the species there is no doubt about their species status. Further studies using allozyme data is necessary to confirm the hybrid zone in Slovenia and the level of gene flow between both species.

One of the pivotal questions regarding both Leptidea species is their origin. Given the wide overlap in the distribution of both species, there is no clear indication of allopatric speciation, although the occurrence of East and West Mediterranean refuges has been suggested (Martin et al., 2003). Due to higher heterozygosity L. sinapis is considered a parent species and $L$. reali could have evolved in a southern Iberian refugium during Pleistocene glaciations. There are two major biogeographical aspects contradicting an Iberian origin of $L$. reali. There are no records of $L$. reali in Portugal (Maravalhas, 2003) and the species is also found in Siberia (Mazel, 2001b). Generally the butterfly species of Atlanto-Mediterranean origin do not penetrate further eastwards than northern Italy and western Germany (Kudrna, 2002). Sympatric speciation is even less plausible, as there is only a weak ecological separation and no apparent ethological differences. The origin of both species can only be identified by a large scale phylogeographic study, including populations from throughout their known range.

ACKNOWLEDGMENTS. We are especially grateful to $\mathrm{P}$. Trontelj for his helpful comments at all stages of the study and J. Bulić Murko for assistance in the laboratory. We are thankful to M. Zagmajster for preparation of the distribution map. We also thank T. Lafranchis (GR) and S. Berreta (IT) for their unpublished records, and all volunteers of the Slovenian Atlas project for samples from different parts of Slovenia. We are thankful to M. Konvička (CZ), T. Schmitt (D) and N. Wahlberg (S) for their suggestions and corrections of the manuscript.

\section{REFERENCES}

AbadjIEv S.P. 2001: An Atlas of the Distribution of the Butterflies in Bulgaria (Lepidoptera: Hesperioidea \& Papilionoidea). Zoogeographia Balcanica 1. Pensoft, Sofia-Moscow, $335 \mathrm{pp}$.

Амiet J.L. 2004: Séparation des niches écologiques chez deux espèces jumelles sympatriques de Leptidea (Lepidoptera, Pieridae). Rev. Ecol. (Terre et Vie) 59: 433-452.

Asher J., Warren M., Fox R., Harding P. \& Jeffcoate G. 2001 : The Millennium Atlas of Butterflies in Britain and Ireland. Oxford University Press, Oxford, $433 \mathrm{pp}$.

Aubert J., Barascud B., Descimon H. \& Michel F. 1997: Ecology and genetics of interspecific hybridization in the swallowtails, Papilio hospiton Géné and P. machaon L., in Corsica (Lepidoptera: Papilionidae). Biol. J. Linn. Soc. 60: 467-492.

Beneš J., KonvičKa M., Dvořák J., Fric Z., Havelda Z., PavLičKo A., VRabec V. \& Weidenhoffer Z. 2002: Butterflies of the Czech Republic: Distribution and Conservation I, II. SOM, Praha, $857 \mathrm{pp}$.

Beneš J., KonvičKa M., Vrabec V. \& ZámeČník J. 2003: Do the sibling species of small whites, Leptidea sinapis and L. reali (Lepidoptera, Pieridae) differ in habitat preferences? Biologia 5: 943-951.

BLACK W.C. IV 1997: RAPDPLOT, version 3.0. Distributed by the author. Department of Microbiology, Colorado State University, Fort Collins, CO.
Boecklen W.J. \& Howard D.J. 1997: Genetic analysis of hybrid zones: numbers of markers and power of resolution. Ecology 78: 2611-2616.

Bos F.G., Bosveld M.A., GroenendiJK D.G., Van SwaAy C.A.M, Wijnhoff I. \& De Vlinderstichting 2006: Nederlandse Fauna 7: De dagvlinders van Nederland. Naturalis, KNNV Uitgeverij, EIS-Nederland, 348 pp.

BourgOGNE J. 1963: Réflexions au sujet d'une espèce singulière, Erebia serotina (Nymphalidae: Satyrinae). Alexanor 3: 363-368.

Braby M.F., Vila R. \& Pierce N.E. 2006: Molecular phylogeny and systematics of the Pieridae (Lepidoptera: Papilionoidea): higher classification and biogeography. Zool. J. Linn. Soc. 147: 238-275.

Chu J., Powers E. \& Howard D.J. 1995: Gene exchange in a ground cricket hybrid zone. J. Hered. 86: 17-21.

Clark A.G. \& Lanigan C.M.S. 1993: Prospects for estimating nucleotide divergence with RAPDs. Mol. Biol. Evol. 10: 1096-1111.

De Greef B. \& Triest L. 1999: The use of random amplified polymorphic DNA (RAPD) for hybrid detection in Scirpus from the river Schelde (Belgium). Mol. Ecol. 8: 379-386.

De Puységur K. 1947: Note sur un accouplement entre Zerynthia polyxena-creusa Meig. et Z. rumina-medesicaste Ill. Rev. Fr. Lepid. 11: 10-15.

Descimon H. \& Michel F. 1989: Expériences d'hybridation intra- et interspécifiques dans le genre Zerynthia (Papilionidae). Relativité des critères mixiologiques de l'espèce. Nota Lepid. (Suppl. 1) 12: 28-31.

Descimon H., Genty F. \& Vesco J.P. 1989: L'hybridation naturelle entre Parnassius apollo (L.) et P. phoebus (F.) dans les alpes du sud (Lepidoptera: Papilionidae). Ann. Soc. Entomol. Fr. (N.S.) 25: 209-234.

EMBACHER G. 1996: Beitrag zur Verbreitung und Biologie von Leptidea sinapis (Linnaeus, 1758) und Leptidea reali Reissinger, (1989) (Lepidoptera: Pieridae, Dismorphiinae). Z. Arb. Gem. Öst. Entomol. 48: 107-112.

Felsenstein J. 1993: PHYLIP (Phylogeny inference package), Version $3.57 c$. Department of Genetics, University of Washington, Seattle.

Folmer O.M., Black M., Hoer R., Lutz R. \& Vrijehoek R. 1994: DNA primers for amplification of mitochondrial cytochrome c oxidase subunit I from diverse metazoan invertebrates. Mol. Mar. Biol. Biotechn. 5: 304-313.

Freese A. \& Fiedler K. 2002: Experimental evidence for specific distinctness of the two wood white butterfly taxa, Leptidea sinapis and L. reali (Lepidopterta: Pieridae). Nota Lepid. 25: 39-59.

Freese A. \& Fiedler K. 2004: Unterscheidungsmerkmale von Leptidea sinapis (Linaeus, 1758) und Leptidea reali Reissinger, 1989 (Lepidopterta: Pieridae) und ihre Eignung zur Artbestimmung. Nachr. Entomol. Ver. Apollo N. F. 25: $65-77$.

Friberg M., Bergman M., Kullberg J., Wahlberg N. \& WikLUND C. 2007: Niche separation in space and time between two sympatric sister species - a case of ecological pleiotropy. Evol. Ecol. (in press).

HaLdANE J.B.S. 1922: Sex ratio and unisexual sterility in hybrid animals. J. Genet. 12: 101-109.

Hebert P.D.N., Penton E.H, Burns J.M., Janzen D.H. \& HallWACHS W. 2004: Ten species in one: DNA barcoding reveals cryptic species in the neotropical skipper butterfly Astraptes fulgerator. Proc. Natl. Acad. Sci. USA 101: 14812-14817.

Huelsenbeck J.P. \& Ronquist F. 2001: MrBayes: Bayesian inference of phylogeny. Bioinformatics 17: 754-755. 
Jiggins C.D., Linares M., Mallet J., Naisbit R.E., Salazar C. \& YANG Z. 2001: Sex-linked hybrid sterility in a butterfly. Evolution 55: 1631-1638.

Jug T., Dovč P., Pohar J. \& SnOJ A. 2004: RAPD analysis as a tool for discriminating marble trout from hybrids (marble trout $\times$ brown trout) in the zones of hybridization. J. Anim. Breed. Genet. 121(3): 156-162.

Karlsholt O. 1999: Dagsommerfugleslaegten Leptidea Billberg i Danmark. Har - eller retter havde - vi to Leptidea-arter i Danmark? Lepidoptera (Copenhagen) 7: 237-249.

Kolligs D. 2003: Schmetterlinge Schleswig-Holsteins. Atlas der Tagfalter. Dickkopffalter und Widderchen. 2nd ed. Wachholtz, Neumünster, 212 pp.

Kristal P.M. \& NäSsig W.A. 1996: Leptidea reali Reissinger, 1989 auch in Deutschland und einigen anderen europäischen Ländern (Lepidoptera: Pieridae). Nachr. Entomol. Ver. Apollo N. F. 16: 345-361.

KudRnA O. 2002: The Distribution Atlas of European Butterflies. Oedippus 20, Apollo Books, Stenstrup, 343 pp.

LAŠTƯVKA Z., KRÁLíČEK M., JAKEŠ O. \& ŠTť̌rba V. 1995: Leptidea reali - eine neue Weissling-Art in der Tschechischen Republik und in der Slowakei (Lepidoptera: Pieridae). Klapalekiana 31: 35-39 [in Czech, German abstract].

LoRKović Z. 1993: Leptidea reali Reissinger 1989 (= lorkovicii Real 1988), a new European species (Lepid., Pieridae). Nat. Croatica 2: 1-26.

Maravalhas E. 2003: As Borboletas de Portugal. Vento Norte, Porto, $400 \mathrm{pp}$.

Martin J.F., Gilles A. \& Descimon H. 2003: Species concepts and sibling species: the case of Leptidea sinapis and Leptidea reali. In Boggs C.L., Watt W.B. \& Ehrlich P. (eds): Butterflies. Ecology and Evolution Taking Flight. University of Chicago Press, Chicago, pp 459-476.

MAZel R. 2000: Le polymorphisme de deux "espèces-jumelles" Leptidea sinapis L. et L. reali Reissinger en France (Lepidoptera: Pieridae). Première partie. Linn. Belg. 17: 277-286.

MAzel R. 2001a: Le polymorphisme de deux "espècesjumelles" Leptidea sinapis L. et L. reali Reissinger en France (Lepidoptera: Pieridae). Deuxième partie. Linn. Belg. 18: 37-43.

Mazel R. 2001b: Une sous-espèce asiatique de Leptidea reali Reissinger: L. reali yakovlevi ssp. nova (Lepidoptera, Pieridae, Dismorphiinae). Linn. Belg. 18: 103-104.

Mazel R. \& Leestmans R. 1996: Relations biogéographiques, écologiques et taxonomiques entre Leptidea sinapis Linné et L. reali Reissinger en France, Belgique et régions limitrophes (Lepidoptera: Pieridae). Linn. Belg. 15: 317-326.

Mazel R. \& Leestmans R. 1999a: Séparation biométrique des Leptidea sinapis L., morsei Fenton et reali Reissinger. Linn. Belg. 17: 46-52.

Mazel R. \& Leestmans R. 1999b: Seconde contribution à l'étude des relations entre Leptidea sinapis Linné et L. reali Reissinger en France, Belgique et quelques autres contrées européennes (Lepidoptera: Pieridae). Linn. Belg. 17: $155-168$.

Mikuliček P., Kautman J., Zavadil V. \& Pialek J. 2004: Natural hybridization and limited introgression between the crested newts Triturus cristatus and T. dobrogicus (Caudata: Salamandridae) in Slovakia. Biologia (Suppl. 15) 59: 211-218.

Naisbit R.E., Jiggins C.D., Linares M. \& Mallet J. 2002: Hybrid sterility, Haldane's rule, and speciation Heliconius cydno and H. melpomene. Genetics 161: 1517-1526.
Negro J.J., Torres M.J. \& Godoy J.A. 2001: RAPD analysis for detection and eradication of hybrid partridges (Alectoris rufa $\times$ A. graeca) in Spain. Biol. Cons. 98: 19-24.

Nelson B., Hughes H., Nash R. \& Warren M. 2001: Leptidea reali Reissinger 1989: a butterfly new to Britain and Ireland. Entomol. Rec. 113: 97-101.

Nylander J.A.A. 2004: MrMmodeltest v2.2. Program distributed by the author. Evolutionary Biology Centre, Uppsala University.

PALMQVist G. 1999. Interesting finds of Macrolepidoptera in Sweden in 1973. Entomol. Tidskr. 120: 59-74 [in Swedish].

Porter A.H. \& Geiger H.J. 1995: Limitations to the inference of gene flow at regional geographic scales - an example from the Pieris napi group (Lepidoptera: Pieridae) in Europe. Biol. J. Linn. Soc. 54: 329-348.

Porter A.H., Wenger R., Geiger H., Scholl A. \& Shapiro A.M. 1997: The Pontia daplidice-edusa hybrid zone in nothwestern Italy. Evolution 51: 1561-1573.

Posada D. \& Crandall K.A. 1998: MODELTEST: Testing the model of DNA substitution. Bioinformatics 14: 817-818.

Presgraves D.C. 2002: Patterns of postzygotic isolation in Lepidoptera. Evolution 56: 1168-1183.

RAJORA O.P. \& RAHMAN M.H. 2003: Microsatellite DNA and RAPD fingerprinting, identification and genetic relationships of hybrid poplar (Populus $\times$ canadensis) cultivars. Theor. Appl. Genet. 106: 470-477.

RÉAL P. 1962: Un phénomène écologique singulier, mais complèxe, l'amphiphénotisme, observé chez les piérides. Ann. Sci. Univ. Besançon (Sér. II) 17: 87-95.

RÉAL P. 1988: Lépidoptères nouveaux principalement jurassiens. Mém. Comité de Liaison Rech. Ecofaunist. Jura 4: 1-28.

Reissinger E. 1989: Checkliste Pieridae Duponchel, 1835, der Westpalaearktis (Europa, Nordwestafrika, Kaukasus, Kleinasien). Atalanta 20: 149-185.

Reverdin J. 1920: Note sur Melitaea athalia Rott. et diagnose d'une espèce nouvelle. Bull. Soc. Entomol. Fr. 25: 319-321.

REVERDIN J. 1922. Melitaea athalia Rott. et Melitaea pseudathalia nova species (?). Bull. Soc. Lépid. Genève 5: 24-46.

SPERLING F.A.H. 1993: Mitochondrial DNA variation and Haldane's Rule in the Papilio glaucus and P. troilus species groups. Heredity 71: 227-233.

SwOFFoRD D.L. 2001: PAUP* Version $4.0 b 10$ [computer software and manual]. Sinauer Asociates, Sunderland, MA.

Verovnik R., Sket B., Prevorčnik S. \& Trontelj P. 2003: Random amplified polymorphic DNA diversity among surface and subterranean populations of Asellus aquaticus (Crustacea: Isopoda). Genetica 119: 155-165.

WARREN M.S. \& Bourn N.A.D. 1998: Wood white, Leptidea sinapis. Species action plan. Butterfly Conservation, Wareham, Dorset. [online]

URL: http://www.butterfly-conservation.org/species/action plans/wood white/ww action plan.pdf

WIKLUND C. 1977: Courtship behaviour in relation to female monogamy in Leptidea sinapis (Lepidoptera). Oikos 29: 275-283.

Williams J.G.K., Kubelik A.R., LivaK K.J., Rafalski J.A., TINGLEY S.T. 1990: DNA polymorphisms amplified by arbitrary primers are usefull as genetic markers. Nucl. Acids Res. 18: $6531-6535$.

Received March 6, 2007; revised and accepted May 11, 2007 